О.Й. Мацько ${ }^{1}$, В.В. Коваль ${ }^{2}$, М.В. Комісаров ${ }^{1}$

${ }_{1}^{1}$ Начіональний університет оборони Украӥни ім. I. Черняховського, Київ

${ }^{2}$ Генеральний штаб Збройних Сил Украӥни, Київ

\title{
ДО ПИТАННЯ ВИЗНАЧЕННЯ ВНЕСКУ ФАКТОРІВ В ЕФЕКТИВНІСТЬ ВИКОНАННЯ ЗАХОДІВ ПРОТИМІННОЇ ДІЯЛЬНОСТІ В УКРАЇНІ
}

У статті розкрито методичний підхід щуодо визначення внеску факторів в ефективність виконання заходів протимінної діяльності. Цей підхід базується на евристичному та експертному методах та передбачає групування факторів, оцінювання їх внеску в ефективність виконання заходів протимінної діяльності з використанням шкали бажаності Харінгтона. Отримані за допомогою підходу результати доцільно використовувати для розробки математичної моделі виконання заходів протимінної діяльності та формування сукупності показників для очүінювання ефективності виконання заходів протимінної діяльності.

Ключеві слова: протимінна діяльність, розмінування, вибухонебезпечний предмет, ефективність, фактори.

\section{Вступ}

Постановка проблеми. Результати аналізу ведення бойових дій на сході нашої країни свідчать, що внаслідок бойових дій значна територія Донецької та Луганської областей забруднена вибухонебезпечними предметами (ВНП). Тільки за попередніми оцінками площа, яка вважається міннонебезпечною, складає: на звільненій території - бли-

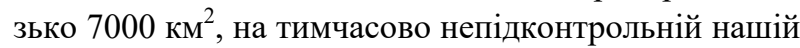
державі території - близько 9000 км² [1-3]. При цьому потрібно враховувати постійні порушення Мінських домовленостей з боку незаконних збройних формувань, які призводять до нових руйнувань та забруднення території ВНП. Наявність значних площ, забруднених ВНП, призводить до втрат як серед військовослужбовців, так і мирного населення. За даними Стокгольмського інституту Миру, Україна за кількістю втрат займає 5 місце, випереджаючи Афганістан, Камбоджу, Малі та Пакистан [1-2].

У таких умовах виникає необхідність проведення в Україні ефективних заходів протимінної діяльності (ПМД), ключову роль в яких повинні відігравати Збройні Сили України. Так, з початку російської агресії Збройні Сили України спільно з іншими підрозділами сил оборони України та міжнародними організаціями розмінували 40 тисяч га території, надали сприяння органам державної влади у реалізації близько 500 проектів з відновлення інфраструктури [4].

Формування обгрунтованих заходів ПМД потребує розроблення відповідного методичного апарату для оцінювання ефективності їх виконання та розроблення відповідних рекомендацій щодо їх впровадження. Здійснення такої роботи неможливе без визначення факторів, які впливають на ПМД, та їх внеску в ефективність виконання визначених заходів, що і обумовлює актуальність цієї статті.

Аналіз останніх досліджень і публікацій. Питанню організації та виконання заходів ПМД в Україні приділялася значна увага в наукових роботах [4-7]. Проте у вказаних роботах були розкриті тільки певні організаційні та нормативно-правові аспекти виконання заходів ПМД, наведені методичні підходи до оцінювання рівня мінної небезпеки. Тому метою статті $є$ розгляд методичного підходу до визначення внеску факторів в ефективність виконання заходів ПМД в Україні.

\section{Виклад основного матеріалу}

Протимінна діяльність - це заходи, що проводяться 3 метою забезпечення національної безпеки та спрямовані на зменшення соціального, економічного та екологічного впливу ВНП на життя та діяльність населення [8].

Основними заходами ПМД в України є [8-11]: інформування про небезпеки від ВНП та навчання щодо запобігання ризикам, пов'язаними із ВНП; проведення розмінування (гуманітарного розмінування); надання допомоги постраждалим особам та здійснення заходів щодо їх реабілітації; знищення надлишкових боєприпасів, боєприпасів, непридатних для подальшого використання та зберігання, а також боєприпасів, що підлягають знищенню відповідно до міжнародних зобов'язань; агітаційнопросвітницька робота щодо незастосування протипіхотних мін.

Результати аналізу виконання заходів ПМД в Україні свідчать, що діяльність органів військового управління Збройних Сил України, насамперед, спрямована на ефективне застосування сил і засобів, 
залучених до виконання цих заходів, що, в свою чергу, передбачає визначення та досягнення відповідних цілей. Ціль ПМД може бути описана вербально або задана певним кількісним показником. 3aвдання ПМД - це ціль, яка конкретизована по термінах та визначена кількісно.

Досягнення кожної цілі та завдань ПМД, які іï деталізують, здійснюється шляхом виконання одного або декількох заходів. Такі заходи можуть бути реалізовані різними варіантами. Під варіантом виконання заходу ПМД розуміють порядок і послідовність виконання заходу виділеним ресурсом у заданих умовах обстановки.

Реалізація кожного варіанту характеризується витратами часу на виконання заходу, витратами ресурсів та досягнутим ефектом від виконання заходу ПМД (рис. 1).

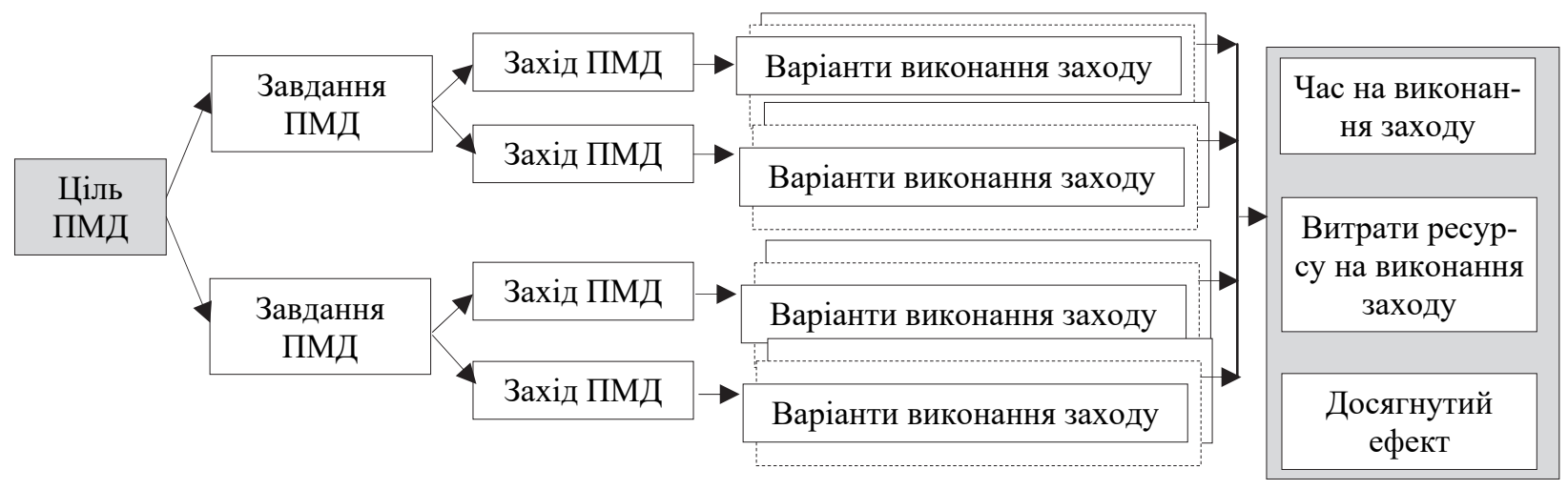

Рис. 1. Послідовність реалізації варіантів виконання заходів протимінної діяльності

Джерело: розроблено авторами.

Основне завдання органів військового управління Збройних Сил України полягає у формуванні різних варіантів досягнення визначених заходів та завдань ПМД, які їх деталізують, всебічному їх аналізі та виборі серед них раціонального.

Проведення такої роботи неможливе без урахування факторів (рушійної сили, будь-якого процесу, явища [12-13]), які впливають на ефективність виконання заходів ПМД.

Під час визначення факторів, які впливають на ефективність виконання заходів ПМД, потрібно враховувати, що більша частина з них не контролюється особою, що приймає (ухвалює) рішення. Для прикладу, це природні умови, об'єктивні закони суспільного розвитку. Такі фактори прийнято називати некерованими [12-13]).

До керованих факторів належать ті, якими можна оперувати в процесі планування та виконання заходів ПМД. Для прикладу - це варіанти виконання заходів ПМД.

У відношенні до ПМД фактори можуть бути зовнішніми та внутрішніми.

Зовнішні фактори відображають вплив зовнішнього середовища, який сприяє успішному виконанню заходів ПМД (корисні фактори) або протидіє їх успішному виконанню (негативні фактори).

Внутрішні фактори відображають взаємовплив рушійних сил всередині ПМД на хід і результат виконання зазначених заходів.

Під ефективністю виконання заходів ПМД за аналогією 3 [14] слід розуміти відношення між кінцевим ефектом, отриманим за визначений час, та витратами ресурсів, необхідних для його досягнення. При цьому ефект є величиною, яка характеризує результат виконання заходу ПМД безвідносно до того, якими зусиллями він досягається.

Наявність значної кількості факторів, які впливають на ефективність ПМД, визначає доцільність їх поділу на відповідні групи, що характеризують їх функціональне призначення. Такий поділ може бути здійснено з використанням евристичного методу.

3 урахуванням досвіду проведення ПМД в Україні та інших країнах світу [1-6; 9-11] доцільно виділити такі основні групи факторів, що впливають на ефективність виконання заходів ПМД:

- юридичні - стан розроблення законодавчих актів з ПМД в Україні; стан розроблення нормативно-правових документів в Міністерстві оборони України, Збройних Силах України та інших складових сектору безпеки та оборони України; стан розроблення стандартів з організації ПМд;

- організаційні - стан розгортання системи управління ПМД в Україні; стан розроблення планів виконання заходів ПМД на середньострокову та довгострокову перспективу в Україні, Міністерстві оборони України, Збройних Силах України та інших складових сектору безпеки та оборони України; стан організації спільної підготовки в Міністерстві оборони України, Збройних Силах України та інших складових сектору безпеки та оборони України 3 питань організації та виконання заходів ПМД; стан організації заходів щодо оцінювання відповідності, 
сертифікації та інспектування ПМД в Україні;

ВНП; інтенсивність застосування противником зброї; спроможності органів військового управління, військових частин (підрозділів) Збройних Сил України та інших складових сектору безпеки і оборони щодо виконання заходів ПМД; можливості зразків (комплексів, систем) озброєння та військової техніки, що залучається до виконання заходів ПМД; ступінь підготовленості особового складу органів військового управління та військових частин (підрозділів) Збройних Сил України до виконання заходів ПМД; рівень організації взаємодії між суб'єктами ведення заходів верифікації ПМД;

- наукові та науково-технічні - ступінь обгрунтованості складу сил і засобів, необхідних для досягнення цілей ПМД; ступінь обгрунтованості потреби в ресурсах (фінансових, матеріальних тощо) для виконання заходів ПМД; рівень розроблення прогнозу розвитку обстановки у сфері ПМД на середньострокову та довгострокову перспективи; ступінь обгрунтованості вимог до озброєння та військової техніки, що планується залучати до виконання заходів ПМД; стан розроблення методологічної бази оцінювання прогнозованої ефективності виконання заходів ПМД;

- економічні - ступінь задоволення необхідним ресурсом (фінансовим, матеріальним тощо) потреб Збройних Сил України та інших складових сектору безпеки і оборони, спланованих заходів ПМД в державних програмах; стан фінансування заходів ПМД за рахунок поточного бюджету; рівень виділення ресурсів країнами-партнерами та іншими урядовими та неурядовими організаціями для ПМД;

- міжнародні - стан розроблення міжнародних
- бойові - ступінь забрудненості місцевості ПМД під час виконання спільних завдань; стан про-

договорів у сфері ПМД в Україні; умови залучення іноземних урядових та неурядових організацій до ПМД в Україні; стан виконання міжнародних конвенцій та договорів 3 питань ПМД;

- інформаційні - рівень висвітлення цілей ПМД та варіантів їх вирішення в Україні та світі; стан обізнаності населення щодо заходів ПМД в Україні; стан організації та проведення заходів агітаційно-просвітницької роботи з питань ПМД;

- природні - природно-кліматичні умови регіонів України, в яких планується виконання заходів ПМД; рельєф місцевості регіонів, в яких планується виконання заходів ПМД; рівень наявності та розробки природних ресурсів регіонів, в яких планується виконання заходів ПМД.

Для визначення внеску кожного фактору в ефективність виконання заходів ПМД доцільно використати метод експертної оцінки [15-17]. При цьому кількість експертів для проведення експертизи повинна бути не менше 10 осіб [17].

Для кожної групи факторів експертами визначаються притаманні їм ознаки (властивості). Чисельні значення кожної ознаки (властивості) визначаються шляхом проведення експертної оцінки в кожній групі з використанням критерію Харінгтона [18]. Якісні значення показників кожної ознаки (властивості) можуть бути охарактеризовані таким чином: дуже важливо; важливо; посередньо; не важливо; зовсім не важливо.

Для переходу від якісного до кількісного оцінювання застосовується безрозмірна шкала бажаності Харінгтона, яка наведена табл. 1.

Значення внеску кожного фактору в ефективність ПМД, що переведено у безрозмірну шкалу бажаності з використанням табл. 1, визначаються через ๆ;, який має інтервал від 0 до 1.

Таблиця 1

Шкала бажаності Харінгтона

\begin{tabular}{|c|c|}
\hline $\begin{array}{c}\text { Якісне значення ознаки } \\
\text { (властивості) фактору }\end{array}$ & $\begin{array}{c}\text { Кількісне значення ознаки } \\
\text { (властивості) фактору }\end{array}$ \\
\hline дуже важливо & $1,00-0,80$ \\
\hline важливо & $0,80-0,63$ \\
\hline посередньо & $0,63-0,37$ \\
\hline не важливо & $0,37-0,20$ \\
\hline зовсім не важливо & $0,20-0,00$ \\
\hline
\end{tabular}

Джерело: розроблено авторами.

Інтегральна оцінка внеску групи факторів в ефективність ПМД проводиться після визначення кількісних показників усієї сукупності факторів та визначається за формулою [18]:

$$
D=\sqrt[N]{\prod_{j=1}^{N} \eta_{j}},
$$

де $\eta_{j}$ - числове значення внеску часткового фактору в ефективність ПМД;

$N$ - кількість факторів в групі.

Отримані результати експертного опитування зводяться в таблицю. Для прикладу, в табл. 2 наведено фрагмент результатів внеску факторів в ефективність ПМД (група юридичних факторів). 
Результати внеску факторів в ефективність ПМД

\begin{tabular}{|c|c|c|c|}
\hline $\begin{array}{l}\text { № } \\
\text { 3/ח }\end{array}$ & $\begin{array}{c}\text { Основні фактори, що впливають } \\
\text { на ефективність ПМД }\end{array}$ & $\begin{array}{l}\text { Якісне значення } \\
\text { внеску фактору }\end{array}$ & \begin{tabular}{|c|} 
Кількісне \\
значення вне-- \\
ску фактору \\
\end{tabular} \\
\hline \multicolumn{4}{|c|}{ Група № 1 - Юридичні фактори } \\
\hline 1. & Стан розроблення законодавчих актів з ПМД в Україні & дуже важливо & 0,91 \\
\hline 2. & $\begin{array}{l}\text { Стан розроблення нормативно-правових документів в } \\
\text { МО України, ЗС України та інших складових сектору } \\
\text { безпеки та оборони України }\end{array}$ & важливо & 0,75 \\
\hline 3. & Стан розроблення стандартів з організації ПМД & посередньо & 0,62 \\
\hline \multicolumn{3}{|c|}{ Інтегральна оцінка внеску групи юридичних факторів в ефективність ПМД } & 1,18 \\
\hline \multicolumn{4}{|c|}{ Група № 2 - Організаційні фактори } \\
\hline 1. & Стан розгортання системи управління ПМД в Україні & дуже важливо & 0,95 \\
\hline 2. & $\ldots$ & $\ldots$ & $\ldots$ \\
\hline
\end{tabular}

Джерело: розроблено авторами.

\section{Висновки}

Запропоновано методичний підхід до визначення внеску факторів в ефективність виконання заходів ПМД, який, на відміну від існуючих, враховує евристичне групування факторів за відповідними групами та дозволяє розрахувати безпосередній внесок кожного фактору в ефективність виконання заходів ПМД.
Подальшими напрямами досліджень $є$ :

1. Формування системи показників і критеріїв оцінювання ефективності виконання заходів ПМД.

2. Розроблення:

- моделі процесу виконання заходів ПМд;

- методики оцінювання ефективності виконання заходів ПМД;

- методики обгрунтування складу (структури) системи (сил і засобів) ПМД.

\section{Список літератури}

1. Карпюк Г. Мінна загроза: щодесята жертва підривів - дитина. Рубрика : веб-сайт. 2019. URL: https://rubryka.com/article/minna-zagroza.

2. Протимінна діяльність в Україні потребує нових підходів. Офіційний сайт 112.UA : веб-сайт. URL: https://ua.112.ua/suspilstvo/protyminna-diialnist-v-ukraini-potrebuie-novykh-pidkhodiv-mintot-390493.html.

3. Протимінна діяльність. Міністерство оборони Украӥни : веб-сайт. URL: https://www.mil.gov.ua/diyalnist/ protiminna-diyalnist.

4. Ганненко С. О. Проблемні питання реалізації заходів протимінної діяльності України під час ведення бойових дій. Надзвичайні ситуачії: попередження та ліквідація. 2020. Том 4. № 1. С. 25-30.

5. Galak A., Kravchuk O., Petrukhin S., Klimov A., Kasian S., Blekot A., Nikitin A., Kotsiuruba V. Rationale for Creating Detonation CO2 Laser for Radioactive Surface Decontamination. Eastern-European Journal of Enterprise Technologies. 2019. Vol. 3. No. 5(99). https://doi.org/10.15587/1729- 4061.2019.169258.

6. Куртсеітов Т. Л., Мосов С. П., Трембовецький М. П., Ясько В. А. Мінна зброя у фокусі сучасних війн і збройних конфліктів. Збірник наукових пращь Центру воєнно-стратегічних досліджень НУОУ. $2020 . \quad$ № 2(69). https://doi.org/10.33099/2304-2745/2020-2- 69/116-121.

7. Коцюруба В. І., Черних І. В., Малюга В. Г., Місюра О. М. До питання оцінювання рівня мінної небезпеки. Системи озброєння і військова техніка. 2019. № 3(59). С. 93-98. https://doi.org/10.30748/soivt.2019.59.12.

8. Про протимінну діяльність в Україні : Закон України від 6 грудня 2018 року № 2642-VIII (зі змінами).

9. Сучасні проблеми забезпечення національної безпеки держави : тези III Міжнародної науково-практичної конферениії (26 листопада 2020 року). Київ : Інститут УДО України КНУ ім. Тараса Шевченка, 2020.

10. Україна. Підтримка протимінних дій : Звіт ICBL від 16.11.2020.

11. Звіт Представництва ХАЛО ТРАСТ в Україні за 2014-2021роки.

12. Шмаков О. М. Словник офіцера внутрішніх військ з воєнно-наукових питань. Харків : Військ. ін-т ВВ МВС України, 2009. 362 с.

13. Новий тлумачний словник української мови у чотирьох томах. Том 4. Київ : Аконіт, 1998944 с.

14. Жуков Г. П., Викулов С. Ф. Военно-экономический анализ и исследование операций. Москва : Воениздат, 1987. $440 \mathrm{c}$.

16. Личковский Е. І., Свердан П. Л. Вища математика. Теорія наукових досліджень. Київ : Знання, 2012. 476 с.

17. Елементи дослідження складених систем військового призначення / Загорка О. М., Мосов С. П., Сбітнєв А. І. та ін. Київ : НАОУ, 2005. 100 с.

18. Harrington E. C. Industrial Quality Control. 1965. 21. № 10 


\section{Відомості про авторів:}

Мацько Олександр Йосипович кандидат військових наук професор начальник інституту забезпечення військ (сил) та інформаційних технологій Національного університету оборони України ім. І. Черняховського, Київ, Україна

https://orcid.org/0000-0003-3415-3358

Коваль Володимир Валерійович кандидат військових наук старший науковий співробітник начальник Воєнно-наукового управління Генерального штабу Збройних Сил України, Київ, Україна https://orcid.org/0000-0002-6209-6779

\section{Комісаров Максим Володимирович} ад’юнкт

Національного університету оборони України ім. І. Черняховського,

Київ, Україна

https://orcid.org/0000-0002-0103-9105
Information about the authors:

\section{Oleksander Matsko}

Candidate of Military Sciences Professor

Chief of Institute of Troops (Forces) Support

and Information Technologies

of Ivan Chernyakhovsky National Defense

University of Ukraine,

Kyiv, Ukraine

https://orcid.org/0000-0003-3415-3358

\section{Volodymyr Koval}

Candidate of Military Sciences

Senior Research

Chief of Military Science Division

of General Staff of the Armed Forces of Ukraine,

Kyiv, Ukraine

https://orcid.org/0000-0002-6209-6779

\section{Maksym Komisarov}

Doctoral Student

of Ivan Chernyakhovsky National Defense

University of Ukraine,

Kyiv, Ukraine

https://orcid.org/0000-0002-0103-9105

\title{
К ВОПРОСУ ОПРЕДЕЛЕНИЯ ВКЛАДА ФАКТОРОВ В ЭФФЕКТИВНОСТЬ ВЫПОЛНЕНИЯ МЕРОПРИЯТИЙ ПРОТИВОМИННОЙ ДЕЯТЕЛЬНОСТИ В УКРАИНЕ
}

А.И. Мацько, В.В. Коваль, М.В. Комисаров

В статье раскрыт методический подход к определению вклада факторов в эффективность выполнения мероприятий противоминной деятельности. Этот подход базируется на эвристическом и экспертном методах и предполагает группировку факторов, оченки их вклада в эффективность выполнения мероприятий противоминной деятельности с использованием шкаль Харрингтона. Полученные с помощью подхода результаты целесообразно использовать для разработки математической модели выполнения мероприятий противоминной деятельности и формирования совокупности показателей для оиенки эффективности выполнения мероприятий противоминной деятельности.

Ключевые слова: противоминная деятельность, разминирования, взрывоопасный предмет, эффективность, факторы.

\section{ON THE DETERMINATION OF THE CONTRIBUTION OF FACTORS TO EFFICIENCY IMPLEMENTATION OF MINE ACTION IN UKRAINE}

\author{
O. Matsko, V. Koval, M. Komisarov
}

The results of the analysis of hostilities in the east of our country show that as a result of hostilities a large area of Donetsk and Luhansk regions is contaminated with explosives. In such circumstances, there is a need for effective mine action in Ukraine, in which the Armed Forces of Ukraine should play a key role. Thus, since the beginning of the Russian aggression, the Armed Forces of Ukraine together with other units of the Defense Forces of Ukraine and international organizations have cleared 40 thousand hectares of territory, provided assistance to public authorities in implementing about 500 infrastructure rehabilitation projects. The formation of sound effective mine action measures requires the development of an appropriate methodological apparatus for evaluating the effectiveness of their implementation and the development of appropriate recommendations for their implementation. The implementation of such work is impossible without identifying the factors that affect the effective mine action and their contribution to the effectiveness of certain measures, which determines the relevance of this article. The main task of the military administration of the Armed Forces of Ukraine is to form various options for achieving certain measures and objectives of the effective mine action, which detail them, their comprehensive analysis and the choice among them rational. Carrying out such work is impossible without taking into account the factors (driving force, any process) that affect the effectiveness of effective mine action measures. When determining the factors that affect the effectiveness of effective mine action measures, it should be borne in mind that most of them are not controlled by the person making (making) decisions. The presence of a significant number of factors that affect the effectiveness of effective mine action, determines the feasibility of their division into appropriate groups that characterize their functional purpose. This division can be performed using the heuristic method. The article reveals a methodological approach to determining the contribution of factors in the effectiveness of mine action. This approach is based on heuristic and expert methods and involves grouping factors, assessing their contribution to the effectiveness of mine action using the Harrington Desirability Scale. The results obtained using the approach should be used to develop a mathematical model of mine action and the formation of a set of indicators to assess the effectiveness of mine action.

Keywords: mine action, demining, explosive object, efficiency, factors. 